\title{
First demonstration of single-layer InAs/lnP (100) quantum-dot laser : continuous wave, room temperature, ground state
}

\section{Citation for published version (APA):}

Kotani, J., Veldhoven, van, P. J., Vries, de, T., Smalbrugge, B., Bente, E. A. J. M., Smit, M. K., \& Nötzel, R. (2009). First demonstration of single-layer InAs/InP (100) quantum-dot laser : continuous wave, room temperature, ground state. Electronics Letters, 45(25), 1317-1318. https://doi.org/10.1049/el.2009.2558

DOI:

10.1049/el.2009.2558

Document status and date:

Published: 01/01/2009

\section{Document Version:}

Publisher's PDF, also known as Version of Record (includes final page, issue and volume numbers)

\section{Please check the document version of this publication:}

- A submitted manuscript is the version of the article upon submission and before peer-review. There can be important differences between the submitted version and the official published version of record. People interested in the research are advised to contact the author for the final version of the publication, or visit the $\mathrm{DOI}$ to the publisher's website.

- The final author version and the galley proof are versions of the publication after peer review.

- The final published version features the final layout of the paper including the volume, issue and page numbers.

Link to publication

\section{General rights}

Copyright and moral rights for the publications made accessible in the public portal are retained by the authors and/or other copyright owners and it is a condition of accessing publications that users recognise and abide by the legal requirements associated with these rights.

- Users may download and print one copy of any publication from the public portal for the purpose of private study or research.

- You may not further distribute the material or use it for any profit-making activity or commercial gain

- You may freely distribute the URL identifying the publication in the public portal.

If the publication is distributed under the terms of Article 25fa of the Dutch Copyright Act, indicated by the "Taverne" license above, please follow below link for the End User Agreement:

www.tue.nl/taverne

Take down policy

If you believe that this document breaches copyright please contact us at:

openaccess@tue.nl

providing details and we will investigate your claim. 


\section{First demonstration of single-layer $\ln A s / \ln P$ (100) quantum-dot laser: continuous wave, room temperature, ground state}

J. Kotani, P.J. van Veldhoven, T. de Vries, B. Smalbrugge, E.A.J.M. Bente, M.K. Smit and R. Nötzel

Reported is the first InAs/InP (100) quantum-dot (QD) laser operating in continuous-wave mode at room temperature on the QD ground state transition employing a single-layer of QDs grown by metal organic vapour phase epitaxy. The necessary high QD density is achieved by growing the QDs on a thin InAs quantum well (QW). These QDs on the QW laser exhibit a high slope efficiency and a lasing wavelength of $1.74 \mu \mathrm{m}$, which is important for biomedical applications.

Introduction: InAs/InP (100) quantum-dot (QD) lasers operating in continuous-wave $(\mathrm{CW})$ mode at room temperature (RT) on the $\mathrm{QD}$ ground state (GS) transition have been reported, mostly for applications in the $1.55 \mu \mathrm{m}$ telecom wavelength region. These lasers required multiple stacked QD layers for sufficient gain [1,2]. A single-layer InAs QD laser was reported on InP (311)B where the QD density is higher than on InP (100) [3]. In this Letter, we report the first single-layer InAs/InP (100) QD laser operating in CW mode at RT on the QD GS transition. The necessary high QD density is achieved by growing the QDs on a thin InAs quantum well (QW). These single-layer InAs QDs on a QW laser exhibit a higher slope efficiency compared to that of the lasers with multiple stacked conventional QDs. The lasing wavelength is $1.74 \mu \mathrm{m}$. This longer wavelength is technologically important for, e.g., gas sensing and biomedical applications [4].

Device fabrication: The QD lasers were grown by low-pressure metal organic vapour phase epitaxy (MOVPE) on $n$-type InP (100) substrates using trimethyl-indium (TMI), trimethyl-gallium (TMG), tertiarybutylarsine (TBA), and tertiarybutyl-phosphine (TBP) as gas sources. The InAs QDs on QW structures and conventional InAs QDs for reference were placed in the centre of a $500 \mathrm{~nm}$-thick lattice-matched InGaAsP waveguide core with a bandgap at $\lambda_{\mathrm{Q}}=1.25 \mu \mathrm{m}(\mathrm{Q} 1.25)$. For the InAs QDs on the QW structure, the InAs QW was formed under metal stable conditions. [5]. Only TMI was first supplied to an equivalent of 0.56 monolayer (ML) InAs, followed by $0.70 \mathrm{ML}$ InAs. This sequence was repeated to a total thickness of $1.6 \mathrm{~nm}$ InAs. The QDs on top of the QW were grown by switching to normal growth condition with continuous TBA supply. One ML InAs was deposited for QD formation, which is already sufficient owing to a large amount of surface segregated In on the InAs QW. The conventional InAs QDs (single and multiple stacked layers separated by $40 \mathrm{~nm}$ Q1.25) were formed by $3 \mathrm{ML}$ InAs on a $1.5 \mathrm{ML}$ GaAs interlayer. The GaAs interlayer allows the formation of pure InAs QDs on Q layers with small diameter owing to suppression of As/P exchange [6]. The InAs growth rate and growth temperature were $0.70 \mathrm{ML} / \mathrm{s}$ and $515^{\circ} \mathrm{C}$, and the TBA flow rate was $30 \mathrm{sccm}$, which shifts also the lasing wavelength of the conventional QD lasers to around $1.75 \mu \mathrm{m}$. Bottom and top claddings of the laser structures were $500 \mathrm{~nm} n$-InP and $1.5 \mu \mathrm{m} p$-InP completed by a compositionally graded $75 \mathrm{~nm} p$-InGaAsP contact layer. $2 \mu \mathrm{m}$ narrow ridge waveguide lasers were fabricated with cavity lengths of $2 \mathrm{~mm}$ and uncoated cleaved facets

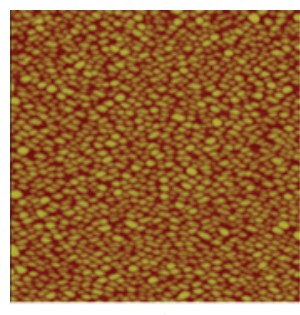

a

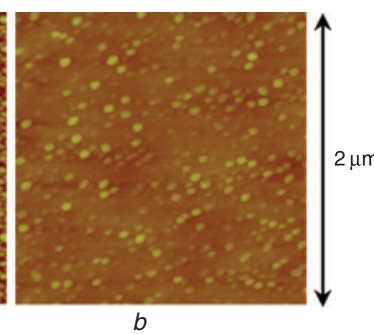

Fig. 1 AFM images of InAs $Q D S$

$a$ Grown on $1.6 \mathrm{~nm}$-thick InAs QW

$b$ Grown on InGaAsP with $1 \mathrm{ML}$ GaAs interlaye

Height contrast is $40 \mathrm{~nm}$

Results: Figs. $1 a$ and $b$ show the atomic force microscopy (AFM) images of the InAs QDs grown on the $1.6 \mathrm{~nm}$ InAs QW and on
Q1.25. The QD density is increased five to six times in the presence of the InAs QW from $6 \times 10^{9} \mathrm{~cm}^{-2}$ for the QD grown on Q1.25 to $3.4 \times 10^{10} \mathrm{~cm}^{-2}$. The QD size is comparable. This increase of the QD density on the InAs QW is attributed to the large amount of strain and surface segregated In after QW growth.

Figs. $2 a-c$ show the electroluminescence and lasing spectra of the single-layer InAs QDs on QW laser and the fivefold and threefold stacked InAs QD lasers taken in CW mode at RT. QD GS lasing is obtained for the single-layer InAs QDs on the QW laser with lasing wavelength of $1.74 \mu \mathrm{m}$ and for the fivefold stacked InAs QD laser Excited state (ES) lasing of the single-layer InAs QDs on the QW laser sets in with increasing injection current, confirming GS lasing at threshold, shown in Fig. $2 a$ at twice the threshold current $\left(I_{t h}\right)$. For the threefold stacked InAs QD laser only lasing from the ES, which provides higher gain owing to the threefold degeneracy, is observed at $1.68 \mu \mathrm{m}$ owing to the lower QD GS gain. For the single layer of InAs QDs lasing is not observed.
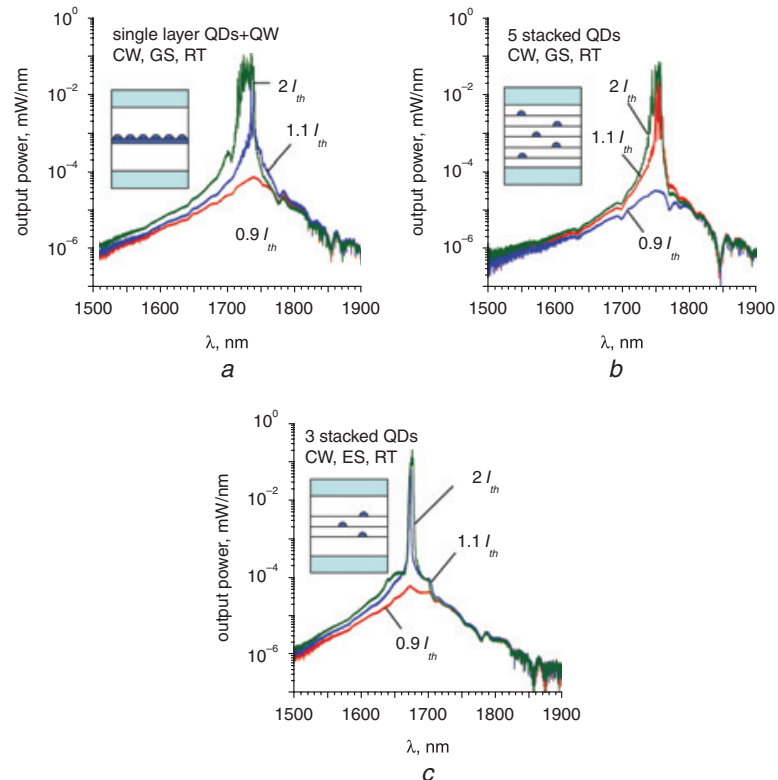

Fig. 2 Electroluminescence and lasing spectra of single-layer InAs QDs on $Q W$ laser and fivefold and threefold stacked InAs QD lasers for injection currents of $0.9 I_{t h}, 1.1 I_{\text {th }}$ and $2 I_{\text {th }}$

a Single-layer InAs QDs on QW laser

$b, c$ Fivefold and threefold stacked InAs QD laser

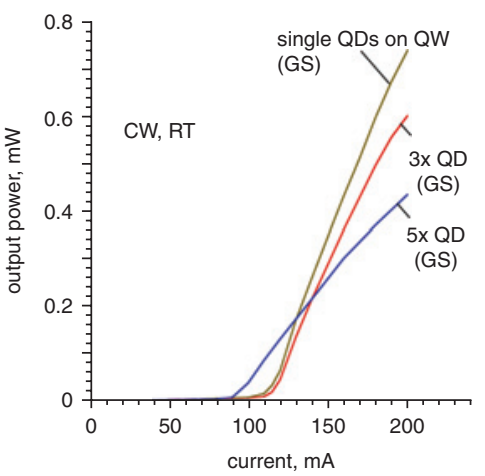

Fig. 3 Light output against injection current curves of single-layer InAs QDs on $Q W$ laser and fivefold and threefold stacked InAs QD lasers Cavity length $(L)$ and width of ridge waveguide $(W)$ are $2 \mathrm{~mm}$ and $2 \mu \mathrm{m}$

Fig. 3 shows the single facet light output against injection current curves of the three QD lasers. $I_{t h}$ and the threshold current density $\left(J_{t h}\right)$ of the single-layer InAs QDs on the QW laser are $110 \mathrm{~mA}$ and $2.75 \mathrm{kA} / \mathrm{cm}^{2}$. The fivefold stacked InAs QD laser reveals $I_{t h}=$ $92 \mathrm{~mA}$ and a $J_{\text {th }}$ of $0.46 \mathrm{kA} / \mathrm{cm}^{2}$ per QD layer. For the threefold stacked InAs QD laser $I_{t h}$ is $116 \mathrm{~mA}$ and $J_{t h}$ per QD layer is increased significantly to $0.97 \mathrm{kA} / \mathrm{cm}^{2}$ owing to the threefold degeneracy of the ES. The threshold current of the single-layer InAs QDs on the QW laser is slightly larger than that of the fivefold stacked InAs QD laser, 
both lasing on the QD GS, but the slope efficiency is larger. This is attained by the high density QDs on the QW, the larger confinement factor for the single-layer QDs on the QW in the centre of the waveguide, and better carrier injection into this single layer.

Conclusions: We have successfully achieved lasing in CW mode at RT on the QD GS transition of single-layer InAs QDs on a QW structure grown by MOVPE on InP (100) substrates. This is enabled by the five to six times increased QD density on the InAs QW compared to that of conventional QDs. The single-layer QDs on the QW laser exhibit a higher slope efficiency compared to that of multiple stacked InAs QD lasers. The lasing wavelength is $1.74 \mu \mathrm{m}$, which is of interest for gas sensing and biomedical applications.

Acknowledgment: This work is supported by the IOP (Innovatiegerichte onderzoeks programma) Photonic Devices programme managed by the Technology Foundation STW (Stichting Technische Wetenschappen) and SenterNovem.

(C) The Institution of Engineering and Technology 2009

8 September 2009

doi: $10.1049 / \mathrm{el} .2009 .2558$

J. Kotani, P.J. van Veldhoven, T. de Vries, B. Smalbrugge, E.A.J.M. Bente, M.K. Smit and R. Nötzel (COBRA Research Institute on Communication Technology, Eindhoven University of Technology, MB Eindhoven 5600, The Netherlands)

E-mail: j.kotani@tue.nl

\section{References}

1 Anantathanasarn, S., Nötzel, R., van Veldhoven, P.J., van Otten, F.W.M., Barbarin, Y., Servanton, G., de Vries, T., Smalbrugge, E., Geluk, E.J., Eijkemans, T.J., Bente, E.A.J.M., Oei, Y.S., Smit, M.K., and Wolter, J.H.: 'Lasing of wavelength-tunable (1.55 $\mu \mathrm{m}$ region) InAs/ InGaAsP/ InP (100) quantum dots grown by metal organic vapour-phase epitaxy', Appl. Phys. Lett., 2006, 89, p. 073115

2 Li, S.G., Gong, Q., Lao, Y.F., He, K., Li, J., Zhang, Y.G., Feng, S.L., and Wang, H.L.: 'Room temperature continuous-wave operation of InAs/ InP (100) quantum dot lasers grown by gas-source molecular-beam epitaxy', Appl. Phys. Lett., 2008, 93, p. 111109

3 Homeyer, E., Piron, R., Grillot, F., Dehaese, O., Tavernier, K., Macé, E., Corre, A. Le., and Loualiche, S.: 'First demonstration of a $1.52 \mu \mathrm{m}$ RT InAs/InP (311)B laser with an active zone based on a single QD layer', Semicond. Sci. Technol., 2007, 22, pp. 827-830

4 Sharma, U., Chang, E.W., and Yun, S.H.: 'Long-wavelength optical coherence tomography at $1.7 \mu \mathrm{m}$ for enhanced imaging depth', Opt. Express, 2008, 16, pp. 19712-19723

5 Tournié, E., and Ploog, K.H.: 'Surface stoichiometry, epitaxial morphology and strain relaxation during molecular beam epitaxy of highly strained $\mathrm{InAs} / \mathrm{Ga}_{0.47} \mathrm{In}_{0.53}$ As heterostructures', J. Cryst. Growth, 1994, 135, pp. $97-112$

6 Ulloa, J.M., Anantathanasarn, S., van Veldhoven, P.J., Koenraad, P.M., and Nötzel, R.: 'Influence of an ultrathin GaAs interlayer on the structural properties of InAs/ InGaAsP/InP (001) quantum dots investigated by cross-sectional scanning tunneling microscopy', Appl. Phys. Lett., 2008, 92, p. 083103 